\title{
Stock And Flow Diagram of Supply-Prices Stabilization Model of The Chicken Meat Industry Supply Network: A Case Study In Daerah Istimewa Yogyakarta (DIY)
}

\author{
Laila Nafisah1', Natasha Putri Larasati², Yuli Dwi Astanti ${ }^{3}$ \\ 1,2,3 Industrial Engineering Department, Faculty of Industrial Engineering, Yogyakarta, Indonesia
}

\begin{abstract}
During the Covid-19 pandemic, the government issued a policy through Large-Scale Social Restrictions and the impact was felt on the unsustainable availability of various food commodities, one of which was broiler chicken meat. Broiler chicken is one of the animal protein food products that is favored by people from various circles because it has a relatively cheaper price compared to other meat commodities that provide animal protein, is easy to obtain, and has good organoleptic quality. The purchasing power of the people of the Special Region of Yogyakarta (DIY) is also increasing due to increased nutritional awareness related to the fulfillment of animal protein. The broiler production process contains uncertainty because it is seasonal. This causes a fluctuating price change. Fluctuations in broiler prices are not a new phenomenon in the DIY. Price fluctuations usually occur at certain times such as during religious holidays and this phenomenon occurs repeatedly every year. So we need a broiler supply chain research to maintain price stability using a dynamic simulation system model of the broiler chicken supply chain in DIY. This study develops a Causal Loop Diagram (CLD) and Stock and Flow Diagram (SFD) of system dynamic model of the broiler supply chain in the DIY and simulates the model using Powersim Studio 10 software. The simulation is confirmed verified and valid, therefore for the next research model can be used to solve the problem by generating policy scenario.
\end{abstract}

Keywords: causal loop, stock and flow diagram, dynamic system, broiler chicken

\section{INTRODUCTION}

This is an open access article under the CC-BY-NC license.

The role and contribution of the poultry industry in economic growth and food security in Indonesia is increasingly significant. This is indicated by the increasing domestic investment in the livestock sub-sector, even since 2018 it is still dominated by poultry commodities, including broilers, which amounted to 85.1\% (Ditjen PKH, 2019). Broiler chicken is one of the food products favored by the people of Indonesia. Demand for broiler chickens is expected to increase along with population growth, increasing income, improving education levels, urbanization, changing lifestyles, and increasing awareness of balanced nutrition. The broiler supply chain has the characteristic that there is a continuous and significant change in the quality of broiler products along the supply chain until the product is consumed. Food products derived from poultry are perishable products. The potential risk of generating losses at each stage of the supply chain is very high and will suppress profits. Therefore, the success of supply chain management in the broiler industry is highly dependent on strong interactions, efficiency, and effectiveness between all supply chain actors from upstream to downstream. In early 2020, the Novel Coronavirus (Covid-19) entered Indonesia.

This causes unrest among citizens around the world, including Indonesia. The Indonesian government has implemented a large-scale social restriction policy as an effort to break the chain of the spread of Covid-19. This policy has a major impact on all sectors of life, especially in the food sector, including broiler agribusiness. The supply chains of various commodities have been seriously disrupted (Widiawati et al, 2020). This condition causes the price of broiler chickens to fluctuate far from the Regulation of the Minister of Trade of the Republic of Indonesia Number 07

Corresponding author:

laila@upnyk.ac.id ; ntashaputri@gmail.com; yulidwi.astanti@upnyk.ac.id 


\section{RSF Conference Series: Engineering and Technology}

Vol. 1 (1), 211-218

Stock And Flow Diagram of Supply-Prices Stabilization Model of The Chicken Meat Industry Supply Network: A Case Study In Daerah Istimewa Yogyakarta (DIY)

Laila Nafisah, Natasha Putri Larasati, Yuli Dwi Astanti

of 2007 which is Rp. 19,000 per kg to Rp. 21,000 per kg. Based on survey data conducted in April 2019, it shows that the price of live broilers at the breeder level ranges from IDR 7,000 - 8,000 per $\mathrm{kg}$. In fact, the cost of production at the farmer level is around IDR 18,700 per kg. This situation lasted for several months, as a result in June 2019, chicken farmers who are members of the DIY Chicken Breeders Association (APAYO) distributed 6,500 chickens for free. The aim is to reduce stocks so that there is a balance between supply and demand and also as a strategy to seek more attention from the government towards the drop in selling price of broilers.

Throughout 2020 along with the Covid-19 pandemic, the broiler chicken industry in the DIY has experienced ups and downs. The price of broiler chickens in the coop reached their lowest point in April at IDR 7,000 per kg. Meanwhile, in early July the price of broiler chickens increased significantly, reaching Rp 42,000 per kg (Pinsar DIY, 2020).

Such unreasonable price fluctuations for chickens are caused by an imbalance between the availability of chickens from suppliers and market demand. When the price of chickens is low and below the cost production, the breeders will suffer a loss. If this is allowed to continue, many breeders will go bankrupt and go out of business, as a result the availability of live chicken supplies will be low and the impact on the low production of broilers. If the supply of broilers is too small compared to market demand, there will be an extreme price hike and it is clear that people's purchasing power will be low. These fluctuating price changes, especially during this pandemic condition, were caused by an imbalance in the amount of production with market demand. This causes broiler agribusiness to manage its supply chain well in order to be able to meet consumer demand with maintained price spreads. Price fluctuations with maintained spreads will contribute greatly to maintaining the purchasing power of broiler consumers in the future. This study will implement a system dynamic model by building a CLD and a SFD using the Powersim software. The CLD and SFD that have been made will then be verified and validated and after being declared valid, the CLD and SFD models created can be used to solve problems related to the stability of broiler prices.

\section{LITERATURE REVIEW}

During the last five years, the broiler commodity market situation is facing problems related to: (1) high fluctuations in the price of day old chicks (DOC), (2) high fluctuations and price disparities, (3) inability to penetrate the export market (Saptana et al., 2017). Several studies concluded that the current structure of the poultry industry is in a guided oligopoly structure, meaning that if the leading livestock company changes prices it will be followed by follower livestock companies (Saptana and Yofa, 2016). Based on research of Septiani and Alexandi (2013), the estimation results show that the variables that have a significant effect on the price cost margin that represents the broiler industry's profits are internal efficiency, growth in output value, and barriers to market entry. In Fitriani et al. (2014), which shows that there is a strong relationship between the structure, behavior and performance of the broiler industry in Indonesia, where the level of integration has a positive and significant relationship to market concentration.

System Dynamic is a method to improve learning ability in a very complex system (Sterman, 2000). The system dynamic develops a feedback mechanism through the simulation method so that it can help overcome the complexity of a problem, understand the sources of resistance to a policy implementation, and help design a more effective policy. Several studies that use system dynamic, such as Nafisah et al., (2017) conducting research on blood supply at PMI. Krisdayanti et al., (2017) use system dynamic to calculate the availability of soybeans in an effort to achieve food selfsufficiency. Whereas Atmaja et al., (2019) discussed the system dynamic of broiler meat availability in Bali Province.

The CLD illustrates the causal relationship between variables with arrows from cause to effect. According to Sterman (2000), there are two types of feedback loops in feedback loops, namely 
reinforcing feedback loops and balancing feedback loops. Reinforcing feedback loop is positive feedback. Balancing feedback loop is a feedback loop that will maintain the stability of a system. A balancing feedback loop is formed when the number of negative signs (-) on the arrows across the loop is odd.

According to Bala et al., (2017) SFD is the underlying physical structure of the system in terms of stock and flow. Stock represents the state or condition of the system, while the flow is changed by decisions based on the condition of the system. In Powersim software, a system that describes the relationship between these variables is called a stock flow. These variables will be depicted through various symbols, mainly the flow symbol which is always associated with the level symbol by means of a thick arrow for the flow process.

\section{RESEARCH METHOD}

The research was conducted on the supply chain of broiler chickens in the DIY. The study was conducted from January to June 2020. The focus of this research is building a CLD and followed by a SFD model using the powersim software. This research was conducted in several stages of research, namely identifying problems and objectives, system conceptualization, system formulation, verification and validation of simulation models. This research is a combination of explanatory research and causal research, namely a combination of secondary data analysis and experimentation. Exploratory research with secondary data analysis to determine situation and problems of the supply chain of broiler chickens in the DIY, while causal research with experiments was to determine the relationship between existing phenomena. This research was conducted using a system dynamic simulation approach to determine what factors affect the stability of prices and supply of broilers in DIY. The data needed in this research are population data in the DIY, data on population projection in the DIY, data on average per capita consumption of broiler chickens in the DIY, data on the population of broiler chickens in the DIY, broiler production data in the DIY, data on broiler prices in the DIY, data on mortality and birth rates in the DIY, and data on the total cost of broiler chicken business in the DIY. Here are the steps for developing a CLD 1) Define problems and goals, 2) Identify the most important elements in the system, 3) Identify the second important (secondary) elementin the system, 4) Identify the third (tertiary) element in the system, 5) Determine cause-and-effect relationships 6) Close loop identification 7) Identify the loops that provide balance (balancing) and which strengthen (reinforcement)Here are the steps in developing SFD. 1) Define problems and goals, 2) Identify the most important elements in the system, 3) Identify the second important (secondary) element in the system, 4) Identify the third (tertiary) element in the system, 5) Identify the variables that represent the stock (one of the characteristics is that it accumulates), 6) Identify the variable that is a flow (having units per unit time from stock) and 7) Ensure the inflow of stock and outflow of stock.

\section{FINDING AND DISCUSSION}

Price stability and availability of broiler chickens are influenced by the subsystem activity in the supply chain system. The subsystem are the production, distribution, and consumption subsystem. Each subsystem consists of elements or elements that are more specific and highly influenced by the development of time, so that the supply chain system for broilers is dynamic. The dynamic model describes the interactions between the elements that make up the broiler supply chain system. The problem of price stability and broiler availability is a fairly complex system problem involving various interacting and integrated components and variables.

The fluctuating price changes, especially during this pandemic, are caused by an imbalance between the supply and demand in the market. The volatility of the price and availability of broilers in the DIY can be seen as a system dynamic problem that changes over time and is influenced by 


\section{RSF Conference Series: Engineering and Technology \\ Vol. 1 (1), 211-218}

Stock And Flow Diagram of Supply-Prices Stabilization Model of The Chicken Meat Industry Supply Network: A Case Study In Daerah Istimewa Yogyakarta (DIY)

Laila Nafisah, Natasha Putri Larasati, Yuli Dwi Astanti

factors that are also dynamic. The system dynamics model developed is limited to matters relating to production, distribution and demand. This model is made based on the identification of problems poured into the CLD, formulated in SFD and then simulated using Powersim software. The conceptual model created is a description of the real system which has interaction between the consumption subsystem, the distribution subsystem, and the production subsystem. is presesnted in Figure 1.

PRODUCTION

DISTRIBUTION

CONSUMPTION

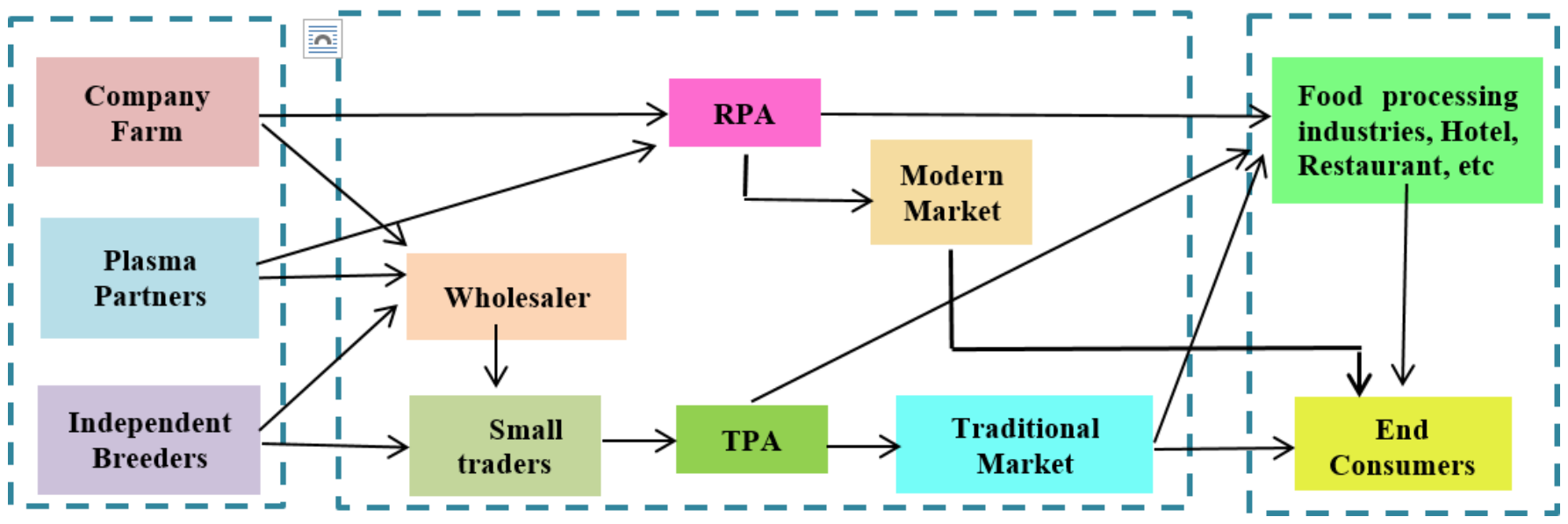

Figure 1. The design of the supply chain model for broiler in the DIY

The interaction between the consumption subsystem, distribution subsystem, and production subsystem can also be represented in the form of a CLD and SFD. The CLD describes the causal events of these variables into a picture that is displayed in the form of arrows that are mutually exclusive. As for the SFD describes the relationship between variables by writing variable formulations based on the relationship between one variable and another. The interaction between these subsystems can be seen in Figure 2.

Table 1. Identification of variables in the broiler supply chain system

\begin{tabular}{|c|c|c|}
\hline Subsystem & Variable & Description \\
\hline \multirow[t]{7}{*}{ Production } & Variable costs & $\begin{array}{l}\text { Production costs consisting of feed costs, fuel costs, } \\
\text { electricity costs, water costs, health care costs } \\
\text { (vaccinations), and DOC purchases }\end{array}$ \\
\hline & Fixed costs & $\begin{array}{l}\text { Production costs which consist of labor costs, capital } \\
\text { goods repair costs, land rental costs, drum construction } \\
\text { costs and the purchase of supporting equipment, tax } \\
\text { costs, livestock service costs, user fees, loan interest } \\
\text { costs, transportation costs, depreciation costs for } \\
\text { capital goods, and other costs }\end{array}$ \\
\hline & Production costs & $\begin{array}{l}\text { Total production costs consisting of variable costs and } \\
\text { fixed costs }\end{array}$ \\
\hline & $\begin{array}{l}\text { Producer profit margin } \\
\text { Producer }\end{array}$ & profit per month \\
\hline & $\begin{array}{l}\text { Break-even point of } \\
\text { production }\end{array}$ & $\begin{array}{l}\text { Direct costs incurred by the producer to produce } 1 \mathrm{~kg} \\
\text { of live broilers }\end{array}$ \\
\hline & $\begin{array}{l}\text { Number of chicken seeds } \\
\text { (DOC) }\end{array}$ & $\begin{array}{l}\text { Number of chicken seeds that will be raised as live } \\
\text { broilers }\end{array}$ \\
\hline & Cage capacity & Number of broilers that can be kept in one cage \\
\hline
\end{tabular}




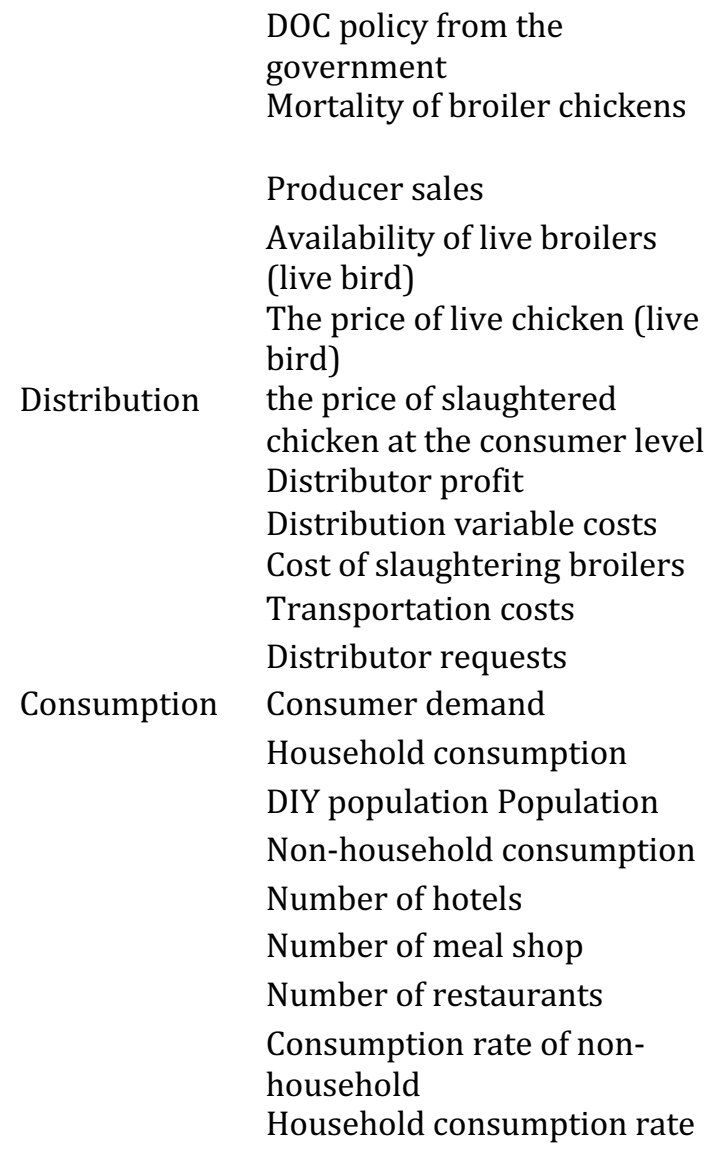

Government policy to regulate the number of DOC

Number of DOC that died in the process of rearing into broiler chickens

Amount of producer sales per month

Availability of live broilers per month

The price of one kilogram of live broiler chicken at the producer level

The price of one kilogram of chicken at the consumer

level

Cumulative distributor profit per month

Operational costs in distribution activities per kilogram

Cost of slaughtering live broilers per kilogram

Transportation costs per kilogram

Number of distributor requests per month

Total consumer demand per month

Total household consumption per month

DIY population per month

Total non-household consumption per month

Accumulated number of hotels in 2020

Accumulated number of meal shop in 2020

Accumulated number of restaurants in 2020

level of consumption of broiler chicken in nonhousehold sector in 2020

Broiler chicken consumption rate in the household sector in 2020

After the CLD is formed, the next step is to build a SFD. The model formulation is divided into 3 parts based on the sub-models, namely production, distribution, and consumption submodels. First is production submodel. Production of broiler chickens is influenced by the DOC and the mortality of broiler chickens during the rearing process. The production value of broiler chickens is the same as the producer's sales because the distributor will buy all the total production of broiler chickens. The more DOC that are kept in one month, the higher the production costs incurred. The production cost of raising broilers comes from fixed costs and variable costs. To determine the selling price of live broilers, producers calculate the cost of production. The cost of production is obtained from the division of production costs by producer sales. The cost of production is considered by producers in determining the selling price of broiler chickens.

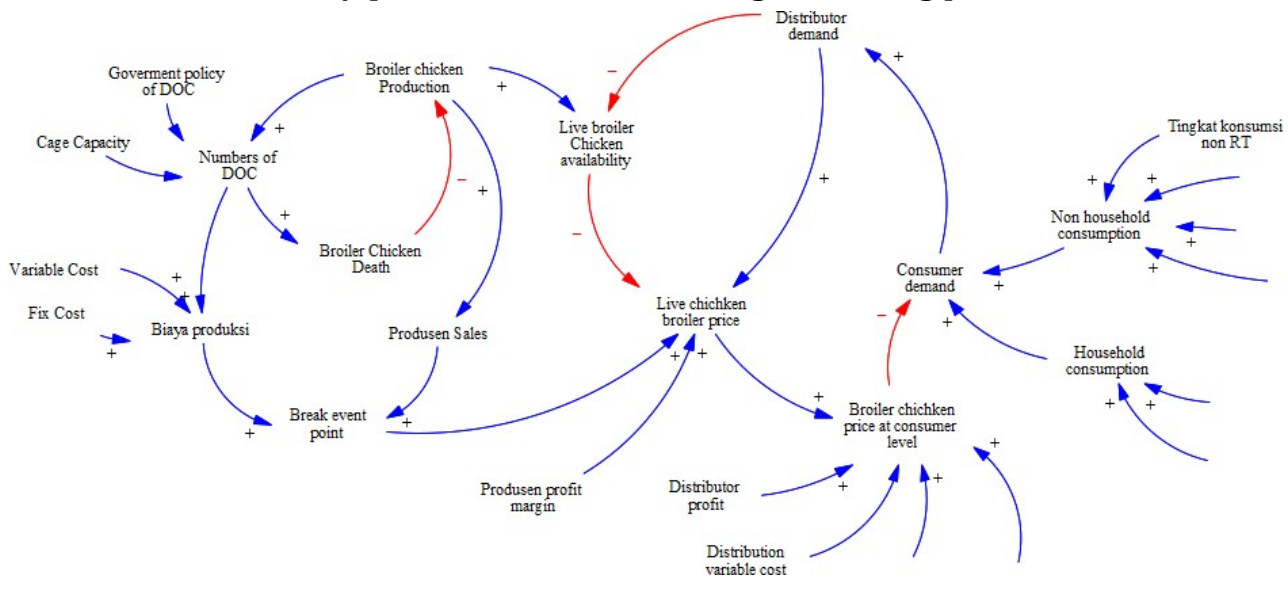

Figure 2. CLD of broiler chicken price stabilization 
The next is distribution sub model. The process of distributing broiler chickens from producers to consumers through a number of intermediaries. Intermediary traders in the distribution of broiler chickens include baskets, brokers, and chicken slaughterhouses (RPA). Breeders will sell live broiler chickens to brokers who will then distribute live chickens to baskets. Bakul will resell the live chickens to the RPA for slaughtering and cleaning the chickens into carcasses of chicken pieces which are then sold to final consumers. These distribution activities create added value that is profitable for each intermediary. The profit value is obtained from the added value given to chicken products along with the movement of products from one distribution intermediary to the last. Distributor profits are cumulative profits from a number of distribution intermediaries, while chicken slaughter costs, transportation costs, and distribution variable costs are other supporting costs in the distribution process. The addition of value to the chicken will form the consumer-level price.

The last is consumption sub model. Estimates of consumer demand for broiler consumption are carried out by taking into account the trends that existed in the past as a basis for analyzing the number of broiler chickens consumed. Therefore, it is necessary to design a comprehensive and integrated plan by considering the situation and conditions in the future. In the representation of the consumption model of broiler chickens, the amount of consumption is determined by consumers consisting of residents of DIY and non-household consumers (hotels, meal shop, and restaurants) with indicators of consumption levels per month. The SFD as seen in figure 3.

Model verification is done to check whether the logic in the model is functioning correctly and there are no errors. Verification also checks for a change from a conceptual model to a computer program that runs correctly. The technique used in the verification of the simulation program in this study is writing and debugging techniques as well as checking the logical relationship between variables and the consistency of units in the model. The results show that the model can run properly and there is no warning sign in the form of a "?" or "\#" on variables or relationships between variables in the model.

Validation is a test to determine the relationship between the model that has been made with real system conditions. Validation test is done by validating the output of the simulation model in this study is the mean absolute percentage error (MAPE) test. The model is declared valid if the deviation between the simulation model output and the real system output can be accepted statistically.

\section{CONCLUSION AND FURTHER RESEARCH}

This paper has presented a methodological framework for understanding change and complexity by building CLD and SFD. The phases and steps of this methodology have been outlined, so that CLD and SFD are formed regarding the stability of broiler prices. And we have indicated that there are three sub-models in the SFD of chicken price stability, namely production, distribution and consumption. The SFD that has been formed has been declared valid. For further research, it can be used to build scenarios or experimental designs on the SFD model to solve problems regarding the stability of broiler prices. 


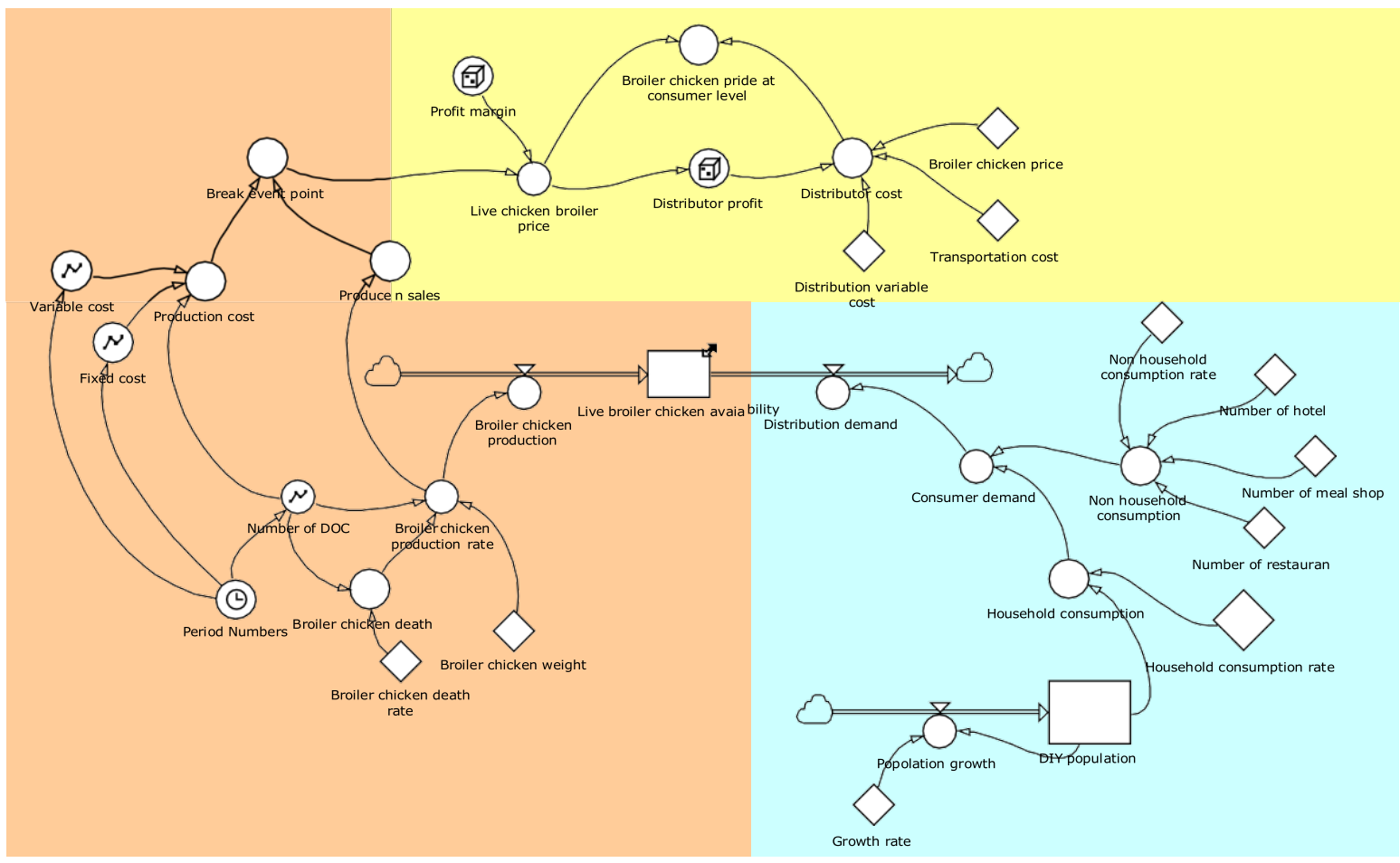

Figure 3. SFD of broiler chicken price stabilization

\section{Acknowledgement}

The authors would like to thank the Institute for Research and Community Service at Universitas Pembangunan Nasional Veteran Yogyakarta, Indonesia, for providing funds for this research.

\section{REFERENCES}

Bala, K. B., Arshad, M. F., \& Noh, M. K. (2017). System Dynamics Modelling and Simulation. Springer. https://doi.org/10.1007/978-981-10-2045-2

Directorate General of Animal Husbandry and Animal Health (Ditjen PKH), Animal Husbandry and Health Statistics. (2019) Jakarta (ID): Directorate General of Animal Husbandry and Animal Health.

Fitriani A., Daryanto H.K., Nurmalina R., Susilowati S.H., Struktur, Perilaku, Dan Kinerja Industri Broiler Indonesia: Pendekatan Model Simultan. J Agro Ekon. 32 (2): 167-186, 2014.

Indonesian Poultry People Association, Daerah Istimewa Yogyakarta (Pinsar DIY), 2020.

IPS Atmaja, IK Satriawan, IWGS Yoga (2019) Sistem Dinamis Ketersediaan Daging Ayam Ras Pedaging (Broiler) Di Provinsi Bali. Jurnal Rekayasa Dan Manajemen Agroindustri 7 (2), 229-242

Krisdayanti, N. K. L., I. K. Satriawan., and I. W. G. S. Yoga., Sistem Dinamik Ketersediaan Kedelai dalam Rangka Swasembada Pangan di Provinsi Bali, Jurnal Rekayasa dan Manajemen Agroindustri, 5(3) : 45-56, 2017.

Nafisah, Laila And Astanti, Yuli Dwi And Astanti, Dini (2017) Simulasi Sistem Dinamis Pengendalian Persediaan Darah Palang Merah Indonesia Kota Yogyakarta. In: Prosiding Seminar Nasional Institut Supply Chain Dan Logistik Indonesia (ISLI), 18 September 2017, Gowa.

Saptana, S., Maulana, M., and Ningsih, R., Produksi Dan Pemasaran Komoditas Broiler Di Jawa Barat, Jurnal Manajemen Dan Agribisnis, 14 (2), 152-164, 2017.

Saptana, S., Yofa, Penerapan Konsep Manajemen Rantai Pasok pada Produk Unggas, Agro-Economic Research Forum, Vol. 34 No. 2, December 2016: 143-161, 2016.

Septiani M. and Alexandi M.F., Struktur Perilaku Kinerja dalam Persaingan Industri Pakan Ternak Di Indonesia Periode Tahun 1986-2010. J Manajemen Agribis, 11 (2): 77-88, 2013. 
RSF Conference Series: Engineering and Technology

Vol. 1 (1), 211-218

Stock And Flow Diagram of Supply-Prices Stabilization Model of The Chicken Meat Industry Supply Network: A Case Study In Daerah Istimewa Yogyakarta (DIY)

Laila Nafisah, Natasha Putri Larasati, Yuli Dwi Astanti

Sterman, J. D., Bussiness Dynamics, System Thinking and Modelling for a Complex World, 2000. Widiawati, I., Sumiati, T., and Hardyanti, P.I., Analisis Rantai Pasok Telur Ayam Ras pada Masa Pandemi Covid-19 pada Kelompok Usaha Peternakan Ayam Ras Petelur Gallus Jaya di desa Setiawaras Kecamatan Cibalong Kabupaten Tasikmalaya, Prosiding Seminar Nasional Polbangtan Magelang, ISBN: 978-623-95866-03, p. 156-166, 2020. 